\title{
Enaminones in a multicomponent synthesis of 4-aryldihydropyridines for potential applications in photoinduced intramolecular electron-transfer systems
}

\author{
Nouria A. Al-Awadi ${ }^{*}$, Maher R. Ibrahim, Mohamed H. Elnagdi, Elizabeth John
} and Yehia A. Ibrahim

\section{Full Research Paper}

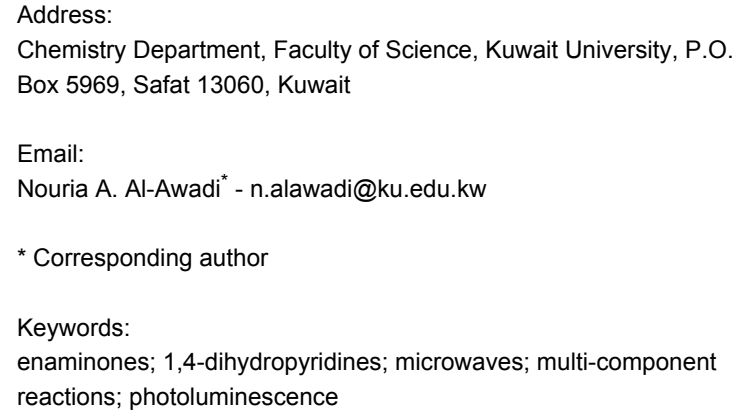

\author{
Beilstein J. Org. Chem. 2012, 8, 441-447. \\ doi:10.3762/bjoc. 8.50 \\ Received: 10 January 2012 \\ Accepted: 07 March 2012 \\ Published: 26 March 2012 \\ Associate Editor: C. Stephenson \\ (C) 2012 Al-Awadi et al; licensee Beilstein-Institut. \\ License and terms: see end of document.
}

\begin{abstract}
An efficient three component reaction with enaminones, primary amines and aldehydes resulted in easy access to 1,4-dihydropyridines with different substituents at the 1-, 3-, 4- and 5-positions. Microwaves improved the reaction yield, reducing also considerably the reaction time and the amount of solvent used. Chiral primary amines gave chiral 1-substituted-1,4-dihydropyridines. The 4-(1-naphthyl) and 4-(phenanthren-9-yl)dihydropyridine derivatives exhibited an interesting photoluminescence behavior, which suggests their potential application as suitable photoinduced intramolecular electron-transfer systems.
\end{abstract}

\section{Introduction}

There is a lot of interest in supramolecular assemblies based on transition-metal ions, which have proved to be useful for a variety of light-induced applications, from molecular machines to systems that mimic chlorophyll photosynthesis [1-6]. Recently, 4-aryl-2,6-dihydropyridine-3,5-dicarboxylates have been investigated as useful organic dyads for the vectorial transport of energy or charge transfer [7,8] (Scheme 1). A few photochemical applications of dyads of this structure have been demonstrated including their use in photosensitive polymers $[9,10]$, in biosensors or in the mapping of enzyme kinetics by means of the fluorescence similarity to NADH [11-13].

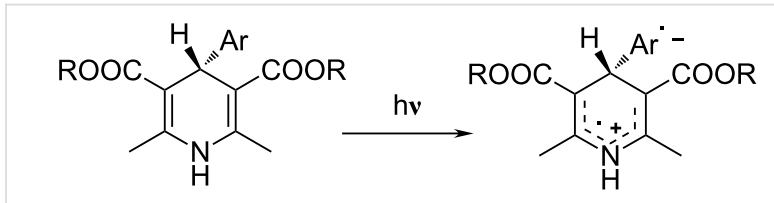

Scheme 1: 2,6-Dihydropyridine-3,5-dicarboxylates as useful organic dyads.

Moreover, there has been recent interest in the synthesis of dihydropyridine derivatives, due to their wide range of biological activity $[14,15]$, by a one-pot three-component reaction 
with aliphatic/aromatic amines, ethyl propiolate and benzaldehyde [14], or by a cascade reaction of 1-phenylpropynone or ethyl propiolate with primary amines and aldehyde [15].

Enaminones are versatile starting materials for the synthesis of many classes of organic compounds and heterocyclic systems $[16,17]$, and are prepared by various methods, for example, $\mathbf{1}$ is readily obtained in excellent yield by the condensation of different methylketones with dimethylformamide dimethylacetal (DMFDMA) [16,17]. In this work we investigated the potential utility of $\mathbf{1}$ in a three-component synthesis of dihydropyridines (DHP) (Scheme 2). This is expected to produce DHP with no substitution at the 2-position and different substituents at the 1-, 3-, 4- and 5-positions. This system contains the characteristic cyclic enaminone chromophore, which is expected to exhibit strong UV absorption with a maximum around $350 \mathrm{~nm}$ and extending to the border of the visible region. In the presence of an appropriate electron-acceptor substituent in position
4, the absorbed UV irradiation can cause intramolecular electron transfer, thus converting light into charge separation over a distance of ca. $6 \AA$. This expectation is based on the recent studies of DHPs containing the enaminocarboxylate chromophore with suitable substituents in the 4-position [7,8]. The DHP products reported in the present synthesis allow an easy method for a wide range of DHP derivatives having this expected characteristic of a photoinduced intramolecular electron-transfer system.

\section{Results and Discussion}

In the present work we have investigated the synthesis of DHPs 2 from 1, aromatic aldehydes, and ammonia or primary amines, in a three-component one-pot reaction. First, we investigated different conditions to achieve this goal (Scheme 2, Table 1). Thus, the reaction (2.1:1:1 molar ratios) of $\mathbf{1}$, different primary amines or ammonium acetate, and aromatic aldehydes in acetic acid under reflux (condition A) for 2-4 h gave the corres-

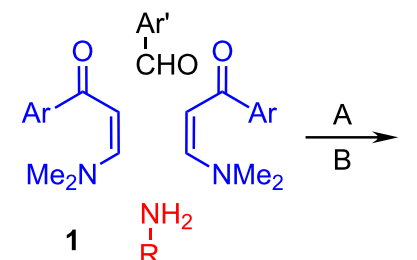

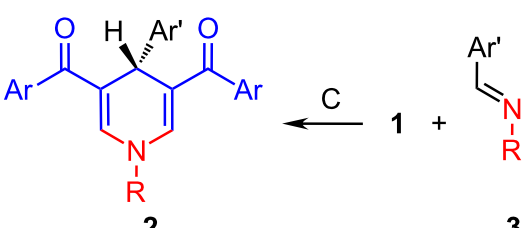

(A) $\mathrm{AcOH}$, reflux $1-3 \mathrm{~h}, 66-86 \%$

(B) $\mathrm{AcOH}, \mathrm{MW}, 150^{\circ} \mathrm{C}, 2 \mathrm{~min}, 84-95 \%$

(C) $\mathrm{AcOH}$, reflux $1-3 \mathrm{~h}, 74-85 \%$

Scheme 2: Synthesis of dihydropyridine derivatives from enaminones.

\begin{tabular}{|c|c|c|c|c|}
\hline Compound & $\mathrm{R}$ & $\mathrm{Ar}$ & Ar' & Conditions (\% yield) \\
\hline $2 a$ & $\mathrm{H}$ & $\mathrm{C}_{6} \mathrm{H}_{5}$ & $\mathrm{C}_{6} \mathrm{H}_{5}$ & A (68), B (94) \\
\hline $2 b$ & $\mathrm{H}$ & $\mathrm{C}_{6} \mathrm{H}_{5}$ & $p-\mathrm{ClC}_{6} \mathrm{H}_{4}$ & A (70), B (92) \\
\hline $2 c$ & $\mathrm{H}$ & $\mathrm{C}_{6} \mathrm{H}_{5}$ & $p-\mathrm{CH}_{3} \mathrm{C}_{6} \mathrm{H}_{4}$ & $A(72)$ \\
\hline $2 d$ & $\mathrm{H}$ & 2-thienyl & $\mathrm{C}_{6} \mathrm{H}_{5}$ & $A(74)$ \\
\hline $2 e$ & $\mathrm{H}$ & 2-furyl & $\mathrm{C}_{6} \mathrm{H}_{5}$ & $A(75)$ \\
\hline $2 f$ & $\mathrm{C}_{6} \mathrm{H}_{5}$ & $\mathrm{C}_{6} \mathrm{H}_{5}$ & $\mathrm{C}_{6} \mathrm{H}_{5}$ & $A(66), B(95), C(76)$ \\
\hline $2 \mathrm{~g}$ & $p-\mathrm{HOC}_{6} \mathrm{H}_{4}$ & $\mathrm{C}_{6} \mathrm{H}_{5}$ & $\mathrm{C}_{6} \mathrm{H}_{5}$ & A (85), B(93), C (74) \\
\hline $2 \mathrm{~h}$ & $\mathrm{C}_{6} \mathrm{H}_{5}$ & 2-furyl & $\mathrm{C}_{6} \mathrm{H}_{5}$ & $A(68), B(91)$ \\
\hline $2 \mathbf{i}$ & $p-\mathrm{CH}_{3} \mathrm{OC}_{6} \mathrm{H}_{4}$ & 2-furyl & $\mathrm{C}_{6} \mathrm{H}_{5}$ & $A(66)$ \\
\hline $2 j$ & $p-\mathrm{CH}_{3} \mathrm{OC}_{6} \mathrm{H}_{4}$ & $p-\mathrm{ClC}_{6} \mathrm{H}_{4}$ & $\mathrm{C}_{6} \mathrm{H}_{5}$ & A (85) \\
\hline $2 k$ & $p-\mathrm{CH}_{3} \mathrm{OC}_{6} \mathrm{H}_{4}$ & 2-thienyl & $\mathrm{C}_{6} \mathrm{H}_{5}$ & $A(86), B(92), C(85)$ \\
\hline 21 & $\mathrm{C}_{6} \mathrm{H}_{5}$ & 2-thienyl & $\mathrm{C}_{6} \mathrm{H}_{5}$ & $A(84), B(90), C(84)$ \\
\hline $2 m$ & $o-\mathrm{NCC}_{6} \mathrm{H}_{4}$ & $\mathrm{C}_{6} \mathrm{H}_{5}$ & $\mathrm{C}_{6} \mathrm{H}_{5}$ & $\mathrm{C}(77)$ \\
\hline $2 n$ & $t$-butyl & $\mathrm{C}_{6} \mathrm{H}_{5}$ & $\mathrm{C}_{6} \mathrm{H}_{5}$ & $A(78), B(84)$ \\
\hline 20 & $\mathrm{CH}_{2} \mathrm{CO}_{2} \mathrm{H}$ & $\mathrm{C}_{6} \mathrm{H}_{5}$ & $\mathrm{C}_{6} \mathrm{H}_{5}$ & $A(73)$ \\
\hline
\end{tabular}

A: 1 (2.1 mmol), ArCHO (1 mmol), amine or ammonium acetate (1 mmol) in AcOH (10 mL) heated under reflux for $1-3 \mathrm{~h}$; $\mathrm{B}: 1$ (2.1 $\mathrm{mmol}), \operatorname{ArCHO}$ $(1 \mathrm{mmol})$, amine or ammonium acetate $(1 \mathrm{mmol})$ in $\mathrm{AcOH}(1 \mathrm{~mL})$ heated in $\mathrm{MW}$ at $150{ }^{\circ} \mathrm{C}$ for $2 \mathrm{~min} ; \mathrm{C}: 1(2.2 \mathrm{mmol}), 3(1 \mathrm{mmol})$ and heating under reflux in $\mathrm{AcOH}$ for $1-3 \mathrm{~h}$. 
ponding dihydropyridine derivatives $\mathbf{2 a - 0}$ in $66-86 \%$ yields. Conducting this reaction in a microwave at $150{ }^{\circ} \mathrm{C}$ increased the yields to $84-95 \%$, decreased the reaction time to $2 \mathrm{~min}$ and also reduced the amount of the solvent used by ca. $90 \%$ (condition B, Scheme 2). Alternatively, compounds 2 were obtained also in good yield by reacting one equiv of the appropriate Schiff's base 3 with two equiv of the enaminones $\mathbf{1}$ in acetic acid (condition $\mathrm{C}$, Scheme 2). Table 1 summarizes the dihydropyridines prepared and the yields obtained under different reaction conditions shown in Scheme 2.

This study was extended to include the synthesis of the chiral (R)-1-(1-phenylethyl)dihydropyridines $\mathbf{4 a}, \mathbf{b}$ obtained in $78 \%$ yield by heating in acetic acid and in $93-94 \%$ yield by microwave irradiation with $R$-1-phenylethylamine in this threecomponent reaction. The bis(dihydropyridines) $\mathbf{5 a}, \mathbf{b}$ were obtained in $75-92 \%$ yield with ethylenediamine and 1,3diaminopropane as the primary amines, respectively. The 4-(1naphthyl)dihydropyridines 6a-f and 4-(phenanthren-9-yl)dihydropyridine derivatives $\mathbf{7 a}, \mathbf{b}$ were obtained from 1-naphthaldehyde and phenanthrene-9-carboxaldehyde in moderate yields after heating in acetic acid for $24 \mathrm{~h}$ (Scheme 3). The intermediate $\mathrm{N}$-substituted enaminones $\mathbf{8}$ were isolated as the main product when the reaction was conducted for shorter time [15]. The longer reaction time and the low yields are attributed to the steric hindrance of the bulky naphthyl and phenanthryl groups. The flanking dione groups in positions 3 and 5 keep the aryl groups in position 4 perpendicular to the dienaminoketone moiety of the dihydropyridine ring, and this is shown in the X-ray crystal structure of $\mathbf{4 b}, \mathbf{6 d}, \mathbf{f}$ and $\mathbf{7 a}$ (Figure 1) [18].
Compounds 6 and 7 are similar to the recently reported dihydropyridine dicarboxylate derivatives and are expected to act as photoinduced intramolecular electron-transfer systems [7,8]. Table 2 shows the UV-vis absorption-emission maxima of compounds $\mathbf{6 a}-\mathbf{f}$ and $\mathbf{7 a}, \mathbf{b}$. The investigated compounds exhibit absorption spectra (Figure 2) with $\lambda_{\max }=277-308 \mathrm{~nm}$ and

\begin{tabular}{|c|c|c|c|c|c|}
\hline Compound $^{a}$ & $\lambda_{\max }{ }^{b}$ & $\log \varepsilon_{\max }$ & $\lambda_{\mathrm{em}}{ }^{\mathrm{c}}$ & $\Phi_{f}^{d}$ & $\Phi_{f}^{e}$ \\
\hline $6 a$ & $\begin{array}{l}383 \\
277\end{array}$ & $\begin{array}{l}4.125 \\
4.019\end{array}$ & $\begin{array}{l}454 \\
456\end{array}$ & 0.0176 & 0.007 \\
\hline $6 b$ & $\begin{array}{l}393 \\
303\end{array}$ & $\begin{array}{l}4.024 \\
4.149\end{array}$ & $\begin{array}{l}457 \\
457\end{array}$ & 0.045 & 0.024 \\
\hline $6 c$ & $\begin{array}{l}398 \\
301\end{array}$ & $\begin{array}{l}3.509 \\
3.608\end{array}$ & $\begin{array}{l}476 \\
476\end{array}$ & 0.050 & 0.030 \\
\hline $6 d$ & $\begin{array}{l}400 \\
294\end{array}$ & $\begin{array}{l}4.243 \\
4.502\end{array}$ & $\begin{array}{l}467 \\
469\end{array}$ & 0.013 & 0.009 \\
\hline $6 e$ & $\begin{array}{l}406 \\
305\end{array}$ & $\begin{array}{l}3.911 \\
3.941\end{array}$ & $\begin{array}{l}486 \\
488\end{array}$ & 0.035 & 0.025 \\
\hline $6 f$ & $\begin{array}{l}389 \\
306\end{array}$ & $\begin{array}{l}4.102 \\
4.327\end{array}$ & $\begin{array}{l}456 \\
456\end{array}$ & 0.034 & 0.017 \\
\hline $7 a$ & $\begin{array}{l}400 \\
301\end{array}$ & $\begin{array}{l}4.152 \\
4.354\end{array}$ & $\begin{array}{l}475 \\
475\end{array}$ & 0.024 & 0.014 \\
\hline $7 b$ & $\begin{array}{l}397 \\
301\end{array}$ & $\begin{array}{l}4.284 \\
4.590\end{array}$ & $\begin{array}{l}466 \\
475\end{array}$ & 0.096 & 0.057 \\
\hline $2 \mathrm{j}$ & $\begin{array}{l}391 \\
308\end{array}$ & $\begin{array}{l}4.140 \\
3.766\end{array}$ & 492 & 0.034 & 0.015 \\
\hline $4 a$ & $\begin{array}{l}396 \\
240\end{array}$ & $\begin{array}{l}3.716 \\
3.745\end{array}$ & 468 & 0.035 & 0.021 \\
\hline
\end{tabular}

aAll spectra were measured for a $1 \times 10^{-4} \mathrm{M}$ solution in acetonitrile; babsorption and excitation; ' ${ }^{2}$ mission; d daking quinine bisulfate $\Phi_{\mathrm{f}}=$

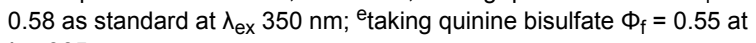
$\lambda_{\text {ex }} 365 \mathrm{~nm}$.<smiles>CC(C(=O)C1=CN(C(C)c2ccccc2)C=C(C(=O)[Al])[C@H]1c1ccccc1)c1ccccc1</smiles>

\section{4}

a, $\mathrm{Ar}=\mathrm{Ph}$

b, $\operatorname{Ar}=2$-thieny

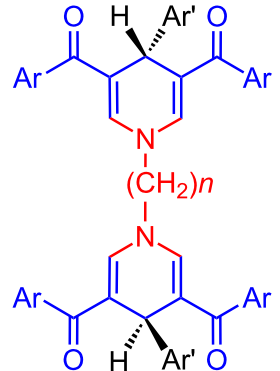

5

a, $n=2$

b, $n=3$ $\mathrm{Ar}=\mathrm{Ar}^{\prime}=\mathrm{Ph}$<smiles>[R]N1C=C(C(=O)[18OH])C([NH3+])([18OH])C(C(=O)[Al])=C1</smiles>

6

a, $\overline{R=H, A r}=P h$

b, $\mathrm{R}=\mathrm{Ar}=\mathrm{Ph}$

c, $\mathrm{R}=p-\mathrm{CH}_{3} \mathrm{OC}_{6} \mathrm{H}_{4}, \mathrm{Ar}=\mathrm{Ph}$

d, $\mathrm{R}=\mathrm{Ar}=p-\mathrm{CH}_{3} \mathrm{OC}_{6} \mathrm{H}_{4}$

e, $\mathrm{R}=p-\mathrm{CH}_{3} \mathrm{OC}_{6} \mathrm{H}_{4}, \mathrm{Ar}=p-\mathrm{ClC}_{6} \mathrm{H}_{4}$

f, $\mathrm{R}=p-\mathrm{ClC}_{6} \mathrm{H}_{4}, \mathrm{Ar}=\mathrm{Ph}$

Naph = 1-naphthyl, Phen = 9-phenanthrenyl 


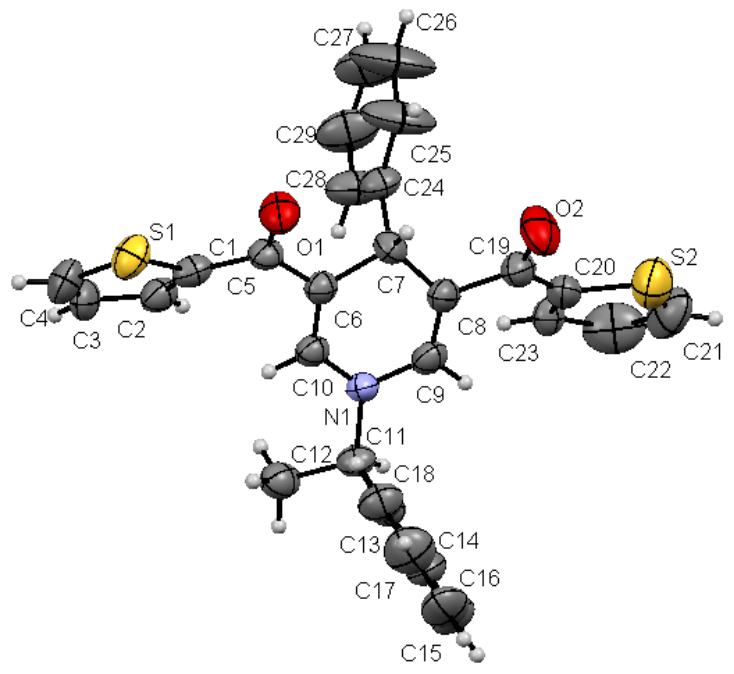

4b

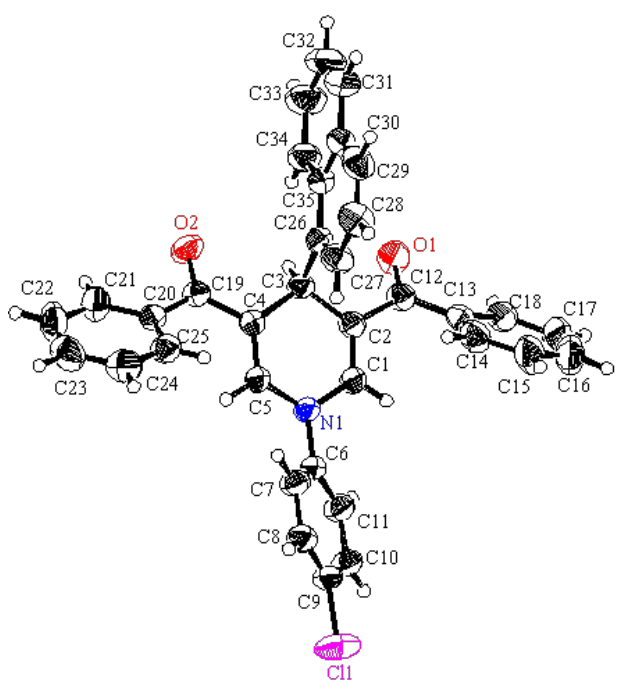

6f

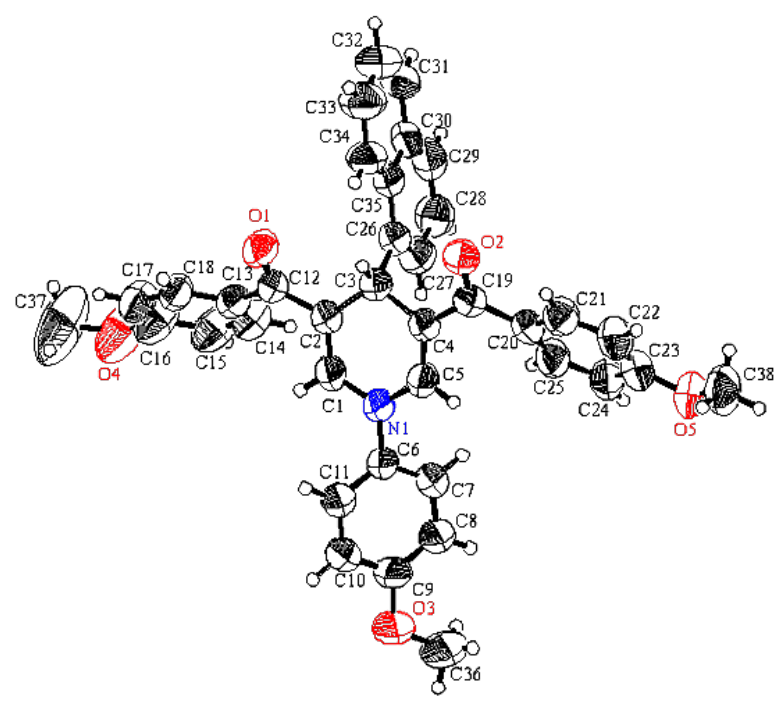

$6 d$

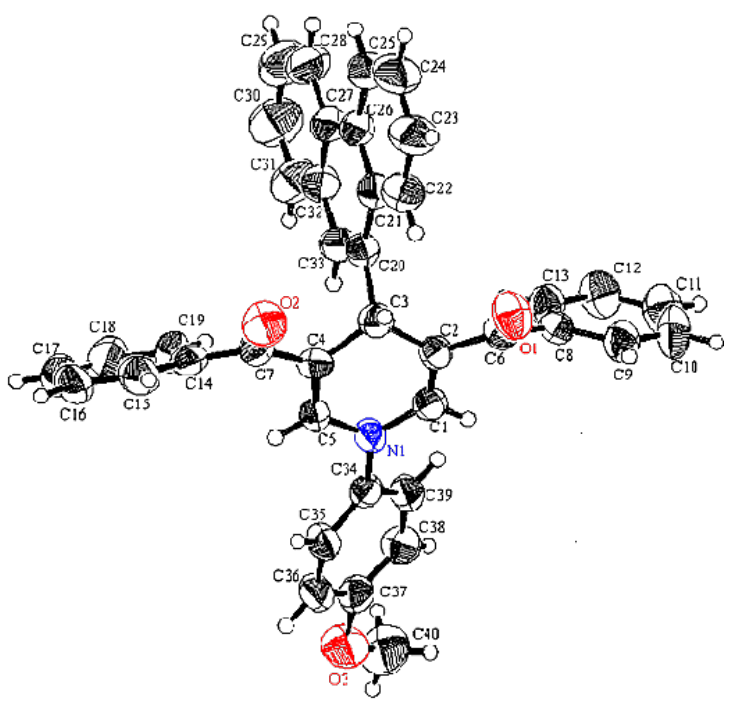

$7 a$

Figure 1: ORTEP of compounds $4 b, 6 d, 6 f$ and $7 a$.

$389-406 \mathrm{~nm}$. The shorter absorption wavelength is attributable to the aryl groups and the longer absorption is due to the DHP moiety [8]. Upon excitation at each of these two $\lambda_{\max }$ these compounds gave fluorescence spectra (Figure 3 and Figure 4) with $\lambda_{\max }=454-492 \mathrm{~nm}$ (Table 2). This photoluminescence behavior of 6 and 7 resembles that of dihydropyridinedicarboxylate derivatives $[7,8]$, which suggests their potential application as suitable photoinduced intramolecular electron-transfer systems. For comparison the absorption and emission spectra of $2 \mathbf{j}$ and $4 \mathbf{a}$ have also been measured, and the results indicate weak emissions relative to $\mathbf{7 b}$. This compound, with the $p$-methoxyphenyl groups in the 1, 3 and 5 positions, showed the most intense absorption (Figure 2) and emission spectra (Figure 4) upon excitation in the $400 \mathrm{~nm}$ ranges. Relative fluorescence quantum yields (Table 2) were measured at $25^{\circ} \mathrm{C}$, taking quinine bisulfate (in $0.1 \mathrm{M} \mathrm{H}_{2} \mathrm{SO}_{4}, 22^{\circ} \mathrm{C}$ ) as standard $\left(\Phi_{\mathrm{f}}=0.58\right.$ at $\lambda_{\mathrm{ex}}=350 \mathrm{~nm}, \Phi_{\mathrm{f}}=0.55$ at $\lambda_{\mathrm{ex}}=365 \mathrm{~nm}$ ).

This synthesis of dihydropyridines was extended to enamino aldehyde 9, enamino ester 11 and enaminonitrile 13. Thus, 1,4dihydropyridine-3,5-dicarboxaldehyde 10a,b, 1,4-dihydropyridine-3,5-dicarboxylate 12 and 1,4-dihydropyridine-3,5-dicar- 


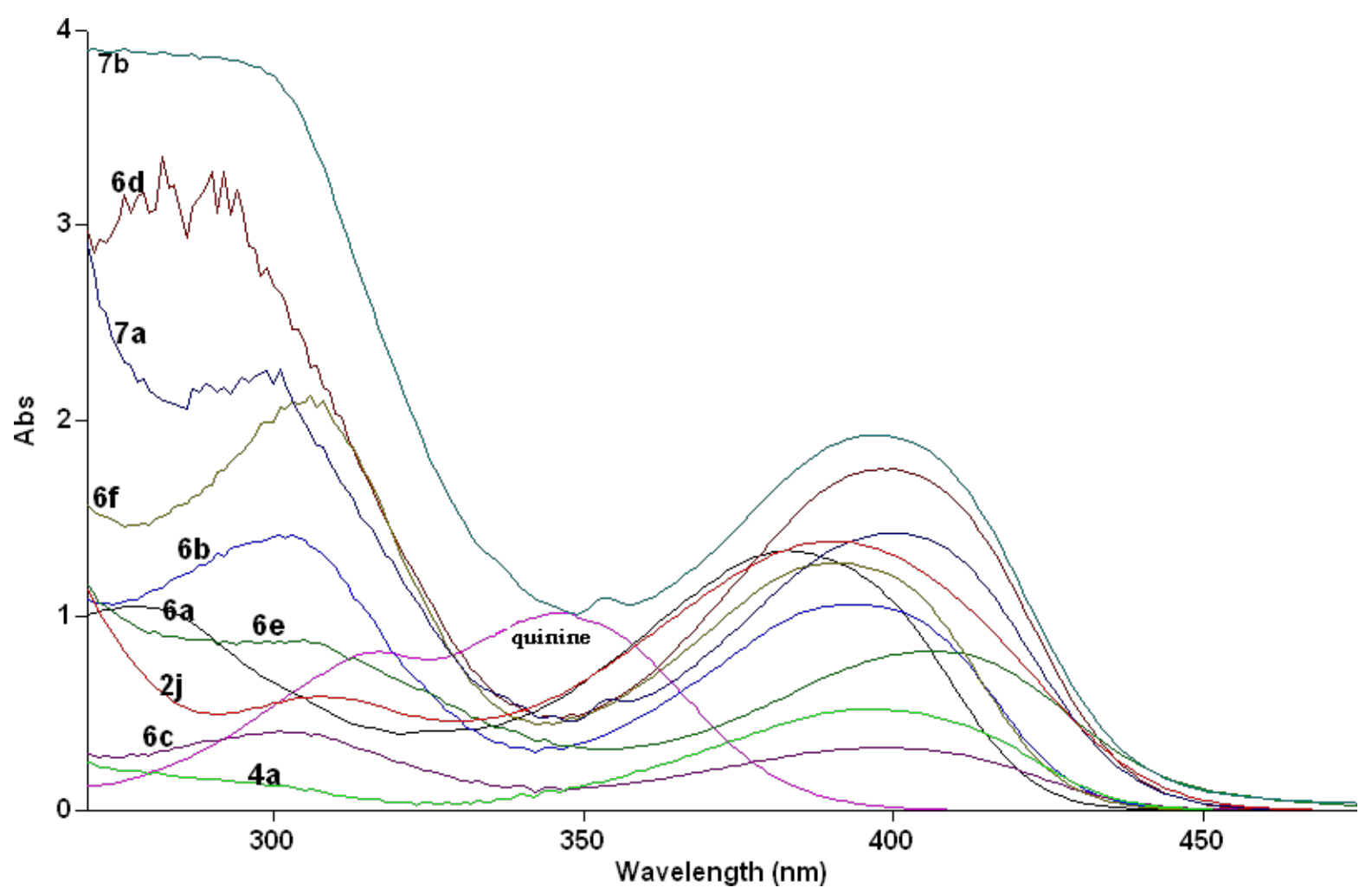

Figure 2: Absorption spectra of compounds $\mathbf{2 j}$, $\mathbf{6 a - f}$ and $\mathbf{7 a}, \mathbf{b}$ in acetonitrile $\left(1 \times 10^{-4} \mathrm{M}\right)$.

\section{A: Excitation at $300 \mathrm{~nm}$ range}

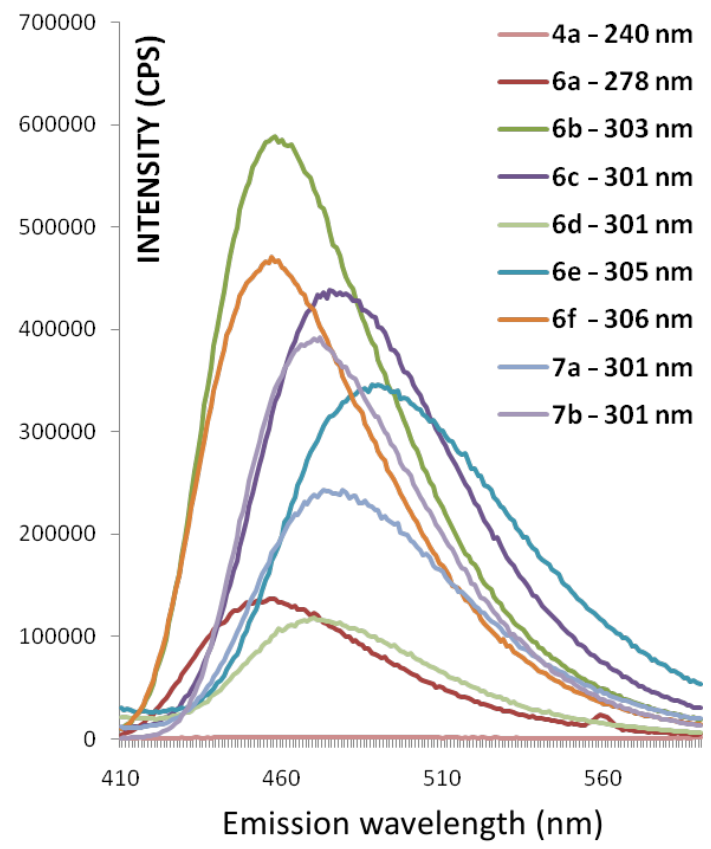

Figure 3: Emission spectra of compounds $4 \mathbf{a}, \mathbf{6 a - f}$ and $\mathbf{7 a , b}$ after excitation at their absorption $\lambda_{\max }$ in the range of $240-306 \mathrm{~nm}$ in acetonitrile $\left(1 \times 10^{-4} \mathrm{M}\right)$.

\section{B: Excitation at $400 \mathrm{~nm}$ range}

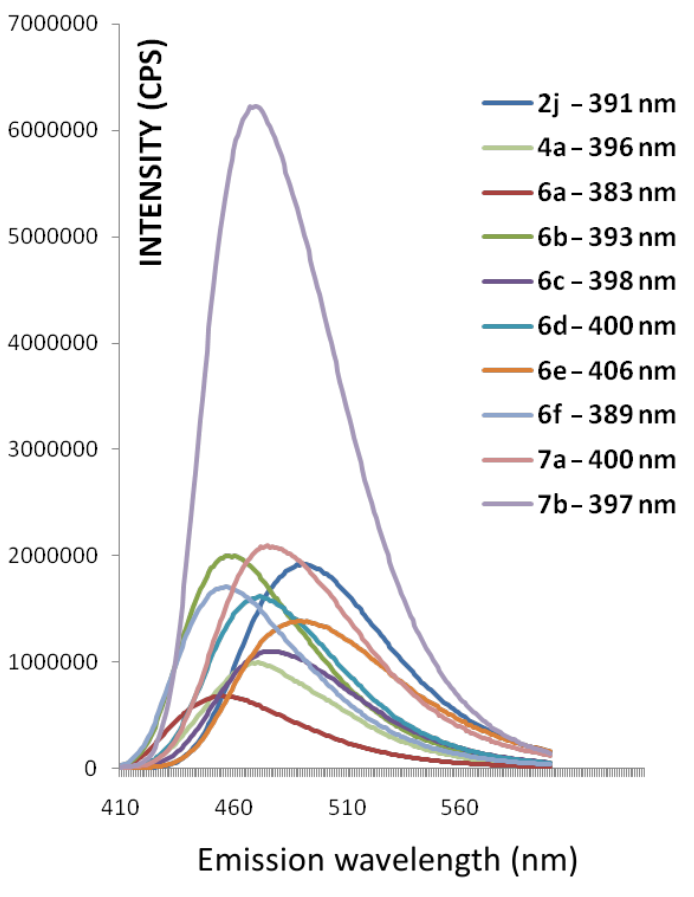

Figure 4: Emission spectra of compounds $2 \mathbf{j}, \mathbf{4 a}, \mathbf{6 a - f}$ and $\mathbf{7 a}, \mathbf{b}$ after excitation at their absorption $\lambda_{\max }$ in the range of $383-406 \mathrm{~nm}$ in acetonitrile $\left(1 \times 10^{-4} \mathrm{M}\right)$. 
bonitrile 14 were successfully obtained by reacting $\beta-N, N$ dimethylaminoacrolein (9), ethyl $\beta-N, N$-dimethylaminoacrylate (11) or $\beta$-piperidinoacrylonitrile (13) with the appropriate aldehyde and primary amine under the same reaction conditions (A, B) (Scheme 4).

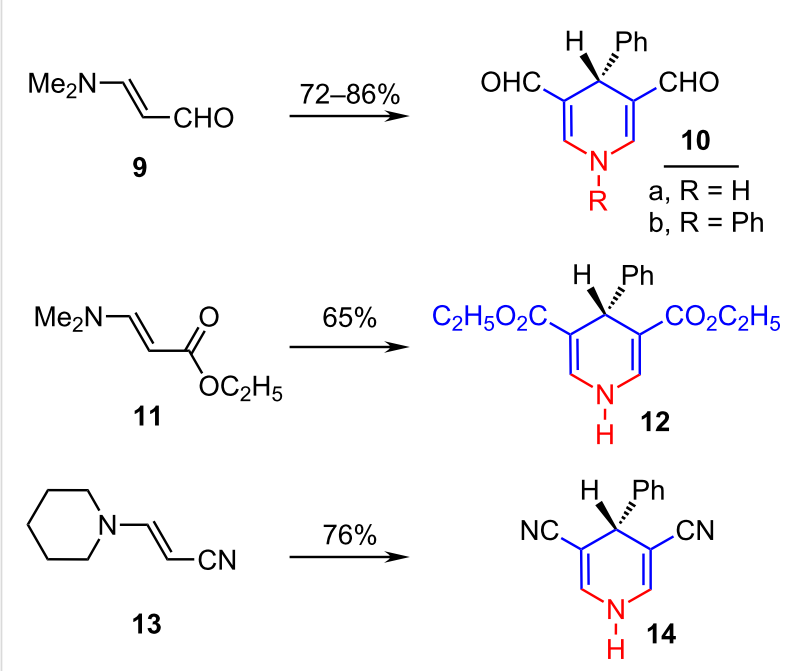

Scheme 4: Synthesis of dihydropyridines from an enamino aldehyde, an enamino ester and an enaminonitrile.

Compounds $2 \mathbf{a}-\mathbf{c}$ and $6 \mathbf{6}$ were readily oxidized to the corresponding pyridine derivatives $\mathbf{1 5 a}-\mathbf{d}$ by stirring in aqueous nitric acid $(70 \%)$ at $5{ }^{\circ} \mathrm{C}$ to room temperature (Scheme 5). The X-ray structure data of 15d (Figure 5) [18] indicates the nonplanarity of the different aryl groups with respect to any of the conjugated systems involved in the pyridine ring.

$$
\begin{aligned}
& 2 \mathbf{a}-\mathbf{c} \text { and } 6 \mathbf{a} \stackrel{70 \% \mathrm{HNO}_{3}}{\longrightarrow} \\
& \text { 70-80\% } \\
& 15
\end{aligned}
$$

Scheme 5: Nitric acid oxidation of dihydropyridines $\mathbf{2 a - c}$ and $\mathbf{6 a}$.

\section{Conclusion}

The present work offers an alternative and efficient method for the synthesis of dihydropyridines with potentially wide applicability, compared to the recently reported [14] synthesis of 3,5dibenzoyl-1,4-disubstituted-dihydropyridine derivatives. The present method has the following advantages:

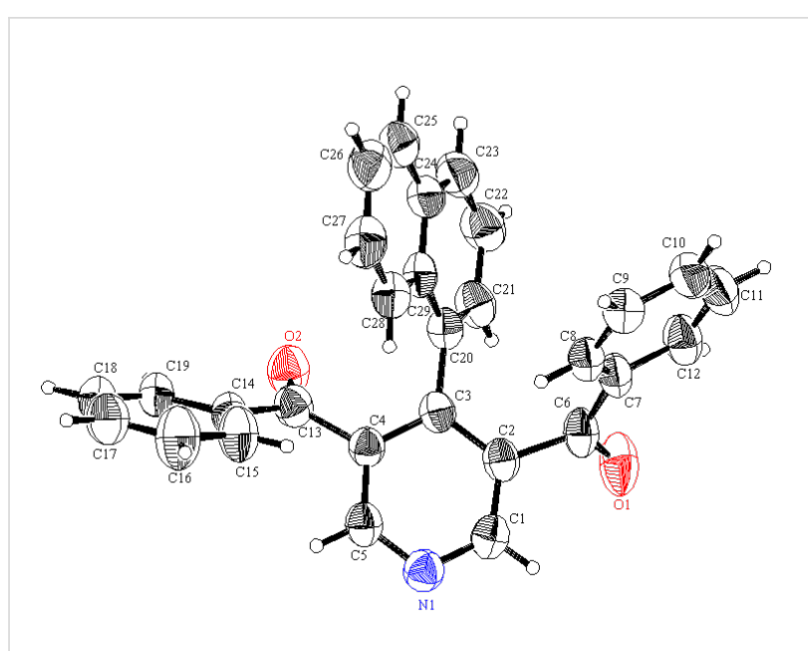

Figure 5: ORTEP of compound 15d

1. The starting enaminones $\mathbf{1}$ can be readily synthesized from any methylketone, whereas the reported method is limited to arylpropynones.

2. This is a one-pot three-component reaction; on the other hand, the reported method involves two steps starting with the reaction of phenylpropynone with a primary amine, followed by reaction with different aldehydes.

3. The synthesis of suitable substituted derivatives, such as 6 and 7, possessing interesting fluorescence and structural characteristics for remarkable photoluminescence behavior, which suggests their potential application as suitable photoinduced intramolecular electron-transfer systems.

4. This method can be extended to the synthesis of enaminoaldehydes 10, enaminoesters 12 and enaminonitriles 14.

\section{Experimental}

General: All melting points are uncorrected. The microwave oven used was a single-mode cavity explorer microwave (CEM Corporation, NC, USA) and irradiation was conducted in heavy-walled pyrex tubes (capacity $10 \mathrm{~mL}$ ). IR spectra were recorded in $\mathrm{KBr}$ disks on a Perkin Elmer System 2000 FTIR spectrophotometer. ${ }^{1} \mathrm{H}$ and ${ }^{13} \mathrm{C}$ NMR spectra were recorded on Bruker DPX 400, $400 \mathrm{MHz}$, Avance II 600, $600 \mathrm{MHz}$ superconducting NMR spectrometers. Mass spectra were measured on GCMSDFS-Thermo and with LCMS by using Agilent 1100 series LC/MSD with an API-ES/APCI ionization mode. Microanalyses were performed on LECO CH NS-932 Elemental Analyzer. The UV-vis absorption spectra were scanned by using a Varian Cary 5 instrument in the wavelength range 250-450 nm with dry, clean quartz cuvettes of $1.0 \mathrm{~cm}$ path length. From the spectra obtained, absorbance values at $\lambda_{\max }$ were used to calculate the extinction coefficient. The emission 
spectra were measured at the same concentration after excitation at the specified $\lambda$ shown in Figure 2, by using a HoribaJobin Vyon Fluromax-4 instrument. Relative fluorescence quantum yields were measured at $25{ }^{\circ} \mathrm{C}$ taking quinine bisulfate (in $0.1 \mathrm{M} \mathrm{H}_{2} \mathrm{SO}_{4}, 22{ }^{\circ} \mathrm{C}$ ) as standard $\left(\Phi_{\mathrm{f}}=0.58\right.$ at $\lambda_{\mathrm{ex}}=$ $350 \mathrm{~nm}, \Phi_{\mathrm{f}}=0.55$ at $\lambda_{\mathrm{ex}}=365 \mathrm{~nm}$ ) [19]. X-rays structures were determined by single-crystal X-ray crystallography RIGAKU RAPID II. Enaminones 1 were prepared according to the previously reported procedure $[16,17]$ and compound 8 was identical with an authentic sample that was prepared as reported [15].

\section{Supporting Information}

\section{Supporting Information File 1}

Experimental procedures and characterization of compounds, including copies of ${ }^{1} \mathrm{H}$ and ${ }^{13} \mathrm{C}$ NMR spectra. [http://www.beilstein-journals.org/bjoc/content/ supplementary/1860-5397-8-50-S1.pdf]

\section{Acknowledgements}

The support of the University of Kuwait received through research grant no. $\mathrm{SC10/07}$ and the facilities of ANALAB and SAF (grants no. GS01/01, GS03/01, GS01/03, GS01/05, GS03/ 08 ) are gratefully acknowledged.

\section{References}

1. Gust, D.; Moore, T. A. Science 1989, 244, 35-41. doi:10.1126/science.244.4900.35

2. Schanze, K. S.; Walters, K. A. Molecular and Supramolecular Photochemistry. Ramamurthy, V.; Schanze, K. S., Eds.; M. Dekker: New York, 1998; Vol. 2, p 75.

3. Gust, D.; Moore, T. A.; Moore, A. L. Chem. Commun. 2006, 1169-1178. doi:10.1039/b514736k

4. Durrant, J. R.; Haque, S. A.; Palomares, E. Chem. Commun. 2006, 3279-3289. doi:10.1039/B601785C

5. Lee, C.-H.; Guo, J.; Chen, L. X.; Mandal, B. K. J. Org. Chem. 2008, 73, 8219-8227. doi:10.1021/jo801293s

6. Armaroli, N. Photochem. Photobiol. Sci. 2003, 2, 73-87. doi:10.1039/b210569a

7. Fasani, E.; Fagnoni, M.; Dondi, D.; Albini, A. J. Org. Chem. 2006, 71, 2037-2045. doi:10.1021/jo052463z

8. Jimenez, A. J.; Fagnoni, M.; Mella, M.; Albini, A. J. Org. Chem. 2009, 74, 6615-6622. doi:10.1021/jo9010816

9. Yamaoka, T.; Yokoyama, S.; Omote, T.; Naitoh, K.; Yoshida, K. J. Photopolym. Sci. Technol. 1996, 9, 293-304. doi:10.2494/photopolymer.9.293

10. Yamaoka, T.; Yokoyama, S.; Omote, T.; Naitoh, K. J. Photopolym. Sci. Technol. 1994, 7, 293-298. doi:10.2494/photopolymer.7.293

11. Wang, H.-W.; Gukassyan, V.; Chen, C.-T.; Wei, Y.-H.; Guo, H.-W.; Yu, J.-S.; Kao, F.-J. J. Biomed. Opt. 2008, 13, 054011. doi:10.1117/1.2975831
12. Ramanujan, V. K.; Jo, J. A.; Cantu, G.; Herman, B. A. J. Microsc. 2008, 230, 329-338. doi:10.1111/j.1365-2818.2008.01991.x

13. Katz, E.; Heleg-Shabtai, V.; Bardea, A.; Willner, I.; Rau, H. K.; Haehnel, W. Biosens. Biolelectron. 1998, 13, 741-756. doi:10.1016/S0956-5663(98)00038-4

14. Mai, A.; Valente, S.; Meade, S.; Carafa, V.; Tardugno, M.; Nebbioso, A.; Galmozzi, A.; Mitro, N.; De Fabiani, E.; Altucci, L.; Kazantsev, A. J. Med. Chem. 2009, 52, 5496-5504. doi:10.1021/jm9008289

15. Yang, J.; Wang, C.; Xie, X.; Li, H.; Li, Y. Eur. J. Org. Chem. 2010, 4189-4193. doi:10.1002/ejoc.201000607

16. Elassar, A.-Z. A.; El-Khair, A. A. Tetrahedron 2003, 59, 8463-8480. doi:10.1016/S0040-4020(03)01201-8

17. Riyadh, S. M.; Abdelhamid, I. A.; Al-Matar, H. M.; Hilmy, N. M.; Elnagdi, M. H. Heterocycles 2008, 75, 1849-1905. doi:10.3987/REV-07-625

18. Crystallographic data (excluding structure factors) for the structures in this paper have been deposited with the Cambridge Crystallographic Data Centre as supplementary publication nos. CCDC 867373 (4b), CCDC 827963 (6d), CCDC 827962 (6f), CCDC 827961 (7a), CCDC 827960 (15d). Copies of the data can be obtained, free of charge, on application to CCDC, 12 Union Road, Cambridge CB2 1EZ, UK, (fax: +44-(0)1223-336033 or email: deposit@ccdc.cam.ac.uk).

19. Eaton, D. F. Pure Appl. Chem. 1988, 60, 1107-1114. doi:10.1351/pac198860071107

\section{License and Terms}

This is an Open Access article under the terms of the Creative Commons Attribution License (http://creativecommons.org/licenses/by/2.0), which permits unrestricted use, distribution, and reproduction in any medium, provided the original work is properly cited.

The license is subject to the Beilstein Journal of Organic Chemistry terms and conditions:

(http://www.beilstein-journals.org/bjoc)

The definitive version of this article is the electronic one which can be found at: doi: $10.3762 /$ bjoc. 8.50 